\title{
Determination of levels of polycyclic aromatic hydrocarbons in soil contaminated with spent motor Engine oil in Abakaliki Auto-Mechanic Village
}

\section{${ }^{11}$ U. OBINI; C.O. OKAFOR; J.N. AFIUKWA}

\author{
${ }^{I}$ Department of Industrial Chemistry, Ebonyi State University, Abakaliki, Ebonyi State, Nigeria. \\ ${ }^{2}$ Department of Pure and Industrial Chemistry, University of Nigeria, Nsukka, Nigeria.
}

Keywords: PAHs, Spent Engine Oil, Soil, Health, Pollution, Abakaliki

\begin{abstract}
Soil samples contaminated with spent motor engine oil collected from Abakaliki auto-mechanic site were analyzed to determine the concentration of polycyclic aromatic hydrocarbon (PAH) components which are often targets in environmental check. Identification and quantification of the PAH components was accomplished using a gas chromatographic system (6890 series and 6890 plus) equipped with a quadrupole Mass Spectrometer (Agilent 5975 MSD) after ultrasonic extraction of the sample and clean up of the extract. The results showed that out of the sixteen USEPA target PAHs (EPA-16) assayed, only six were detected in varying concentrations in $\mathrm{mg} / \mathrm{kg}$. These include Phenanthrene with concentration range of $0.0172 \pm 0.01$ to $0.0193 \pm 0.02$, fluorene $(0.0189 \pm 0.01)$, benzo[a]anthracene $(0.0162 \pm 0.05)$, chrysene $(0.0209 \pm 0.02)$, benzo[b]fluoranthrene $(0.0453 \pm 0.02)$ and benzo[k]fluoranthrene $(0.0389 \pm 0.1)$. The concentration of total PAH components detected in the samples ranged from $0.0184 \pm 0.02$ to $0.1385 \pm 0.2 \mathrm{mg} / \mathrm{kg}$. Implications of PAHs on health were discussed. @JASEM
\end{abstract}

DOI: $\underline{\text { http://dx.doi.org/10.4314/jasem.v17i2.1 }}$

In Nigeria, as in many other countries, petroleum hydrocarbon contamination is widespread. Pollution arising from the disposal of used engine oil is one of the environmental problems in Nigeria and is more widespread than crude oil pollution (Odjegba and Sadiq, 2002). The prevalent mode of indiscriminate disposal of these spent engine oils in the environment calls for urgent attention. Contamination results from mishandling, deliberate disposal, spilling and leakage of petroleum products, such as gasoline, lubricating oils, diesel fuel, heating oils, used or spent engine oils. A survey of Abakaliki capital city of Ebonyi State, Nigeria indicates that apart from the centralized Abakaliki auto-mechanic workshops cluster (popularly called mechanic village or site), there are several other automobile workshops scattered all over the town from which used engine oils, lubricating oils and other solvents containing petroleum hydrocarbons are indiscriminately dumped or spilled on every available space by artisans in the business of auto-repairs. The local utilization of engine oil in Abakaliki has increased in the recent time owing to new status of Abakaliki as a capital city following the creation of Ebonyi State in the last 17 years. This is due to the upsurge in the number of vehicles and other machines that makes use of these lubricants. These unguided practices have worsened the rate at which used engine oils spread and contaminate the soils and water around the town. Studies in autorepair workshop sites have been carried out by many researchers (Ipeaiyeda and Dawodu, 2008). But most of them focused on the study of the implication of heavy metal contamination in soil by these used engine oils without recourse to the effects of other petroleum hydrocarbon pollutants such as the persistent and ubiquitous polycyclic aromatic hydrocarbons (PAH) present in used engine oils. These used oils and solvents form part of the most hazardous wastes commonly generated in auto-repair shops around cities in Nigeria (Ipeaiyeda and Dawodu, 2008 and Iwegbue, 2007). Waste oil is a mixture of different chemicals including petroleum hydrocarbons, chlorinated biphenyls, chlorodibenzofurans, additives, decomposition products and heavy metals that come from engine parts as they wear away (Wang et al., 2000; ATSDR, 1997). Used engine oil, also called spent lubricant or waste engine oil, is usually obtained after servicing and subsequently draining from automobile and generator engines (Sharifi et al., 2007). The exact composition of used oils depends on the origin, extent of use and degradation products that formed in the oil over time or during use. Ekundayo et al., (1989) have shown that noticeable changes in properties occur in soils polluted with petroleum hydrocarbons arising from used engine oils. Oil pollution of soil leads to build up of metals in soil and the eventual translocation in plant tissues (Vwioko et al., 2006). Used engine oil easily migrates into the environment and eventually seeps into water bodies (Olugboji and Ogunwole, 2008).

PAHs belong to a group of over 100 hazardous substances of organic pollutants consisting of two or more fused-benzene aromatic rings. Formation of $\mathrm{PAH}$ is due to incomplete combustion of organic matter through the condensation of ethylenic radicals in the gas phase to form the larger polycyclic compounds (Lane, 1989). Those containing up to four benzene rings are known as light PAHs (1-PAHs) and those containing more than four benzene rings are known as heavy PAHs (h-PAHs). The h-PAHs are more stable and toxic than the 1-PAHs (ATSDR, 1995). According to Comprehensive Environmental Response, Compensation and Liability Act (CERCLA) list of hazardous substances, PAHs 
ranked $7^{\text {th }}$ in 2005 in the biennial ranking of chemicals deemed to pose the greatest possible risk to human health (Christopher, 2008). PAHs have low solubility in water and are highly lipophilic. In water or when adsorbed on particulate matter, PAHs can undergo photodecomposition in the presence of ultraviolet light from solar radiation. In the atmosphere, PAHs can react with ozone, nitrogen oxides and sulphur dioxide, to give diones, nitro- and dinitro-PAHs, and sulphonic acids, respectively. Biologically, PAHs can be degraded by some microorganisms in the soil (WHO, 1987 and ATSDR, 1994). Some have been demonstrated to be mutagenic and carcinogenic in humans (Phillip, 1999). Those PAHs that have not been found to be carcinogenic may, however, synergistically increase the carcinogenicity of other PAHs. The main focus of this study was to find the background levels of PAHs within the ever increasing human effected build-up area of Abakaliki Auto-mechanic village which has become densely populated with residential homes.

\section{MATERIALS AND METHOD}

The Study Area: The study area was Abakaliki automechanic village located along the old AbakalikiOgoja Expressway a few meters to the popular Abakaliki Rice Mill cluster. The Abakaliki, automechanic village lies within Lat. $6.20 \mathrm{~N}$ and Long. $8.10 \mathrm{E}$ (Fig. 1). It is an area mapped out by the government of Ebonyi State for artisans in automobile business which involves constant changing of used motor engine oils. The Abakaliki auto-mechanic village is one of the busiest areas in the town considering the volume of other business activities that sprang up following the new state creation.

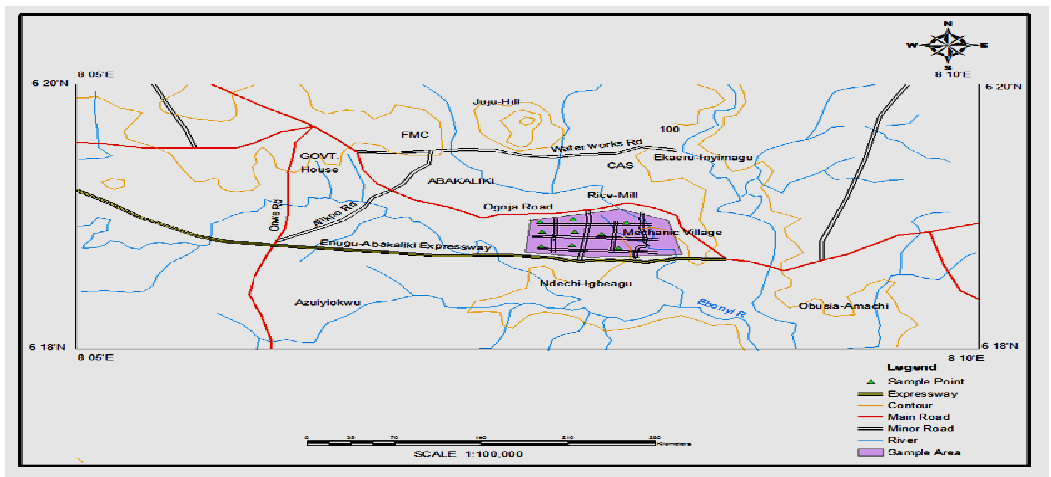

Fig. 1: Map of Abakaliki Showing the Study Area and Sample points

Sampling, Collection and Treatment: The sample area was divided into three sub-areas. In each of the sub-areas, three workshop sites were selected randomly for sample collection. Three soil samples were collected from each sub-area and homogenized into a composite sample. The samples were collected with an improvised soil augur (nitric acid sterilized PVC pipes) in June, 2012 between the hours of 8$10 \mathrm{am}$. A total of nine batch soil samples made into three different composite samples were collected at depth of $0-15 \mathrm{~cm}$, after the removal of the exposed surface according to MCPA method (2008). A thin layer of the composite samples were screened on a filter paper to remove fragments of plants debris and stone. The screened samples were thereafter air-dried in the dark. The dry soil samples were then ground into powder in a ceramic mortar and demagnetized with a magnetic rod and kept in sealed vials labelled EZW, Q265W and NCPW (Table 1). They were preserved in a refrigerator at $4^{\circ} \mathrm{C}$ according to the US-EPA recommended sampling protocols (Method 8100) prior and GC-MS analysis.
Sample Extraction and GC-MS Analysis: Extraction of hydrocarbons from the samples was done with a sonicator (Ultrasonic bath-Elmsonic $\mathrm{S} 40 \mathrm{H}$ ) in accordance with US SW-846 Method 3550. A 10.00g of each of the composite samples was extracted with a 50:50 mixture of acetone and methylene chloride spiked with $1 \mathrm{ml}$ of $\mathrm{PAH}$ internal standard and shaken thoroughly for proper mixing before placing in an ultrasonic bath. The EPA-16 PAHs determination was conducted at Dukoria Laboratories Limited, Warri, Delta State, Nigeria using Gas Chromatographic System (6890 series and 6890 plus) equipped with a dual detector (FID-ECD), dual column and TriPlus AS auto-sampler with helium carrier gas and a quadrupole Mass Spectrometer (Agilent 5975 MSD) based on USEPA method 8100 (EPA, 1984). A $2.00 \mu 1$ of extracts were injected into the GC port set at column conditions: HP-5 crosslinked PH-ME siloxane, Length of $30 \mathrm{~m}$, I.D: $0.25 \mathrm{~mm}$, thickness of $1 \mu \mathrm{m}$ with helium carrier gas set in the spitless, constant flow mode with 1.2 $\mathrm{ml} / \mathrm{min}$ flow rate. Other GC and MS operating set-up were done according to the instrument's method development as specified in the operating instruction 
manual. Identification and quantification of individual PAHs was based on internal calibration standard containing known concentrations of the 16 PAHs (EPA-16). The specificity of the 16 PAHs sought for in the samples was confirmed by the presence of transition ions (quantifier and qualifier) as shown by their retention times which corresponded to those of their respective standards. The measured peak area ratios of precursor to quantifier ion were in close agreement with those of the standards. Results obtained were presented as $\mathrm{mg} / \mathrm{kg}$ concentration per analyte.

\section{RESULTS AND DISCUSSION:}

The concentrations of the 16 EPA Target PAH components $(\mathrm{mg} / \mathrm{kg})$ in the soil samples collected from Abakaliki auto-mechanic site are presented in Table 1 and Fig. 2. The GC-MS fingerprints confirming the presence of these analytes in the samples are shown in Figs. 3-5.

Table 1: Concentrations of 16 EPA Target PAHComponents assayed in the Soil Samples

\begin{tabular}{|c|c|c|c|}
\hline $\begin{array}{ll}\text { PAH } & \text { Component } \\
(\mathrm{mg} / \mathrm{kg}) & \end{array}$ & EZW & Q265W & NCPW \\
\hline Naphthalene & nd & nd & nd \\
\hline Acenaphthalene & nd & nd & nd \\
\hline Acenaphthene & nd & nd & nd \\
\hline Fluorene & nd & nd & $0.0189 \pm 0.4$ \\
\hline Phenanthrene & $\begin{array}{l}0.0184 \pm 0 . \\
22\end{array}$ & $0.0172 \pm 0.2$ & $0.0193 \pm 0.25$ \\
\hline Anthracene & nd & nd & nd \\
\hline Fluoranthene & nd & nd & nd \\
\hline Pyrene & nd & nd & nd \\
\hline Benzo[a]anthracene & nd & $0.0162 \pm 0.3$ & nd \\
\hline Chrysene & nd & $0.0209 \pm 0.4$ & nd \\
\hline $\begin{array}{l}\text { Benzo[b]fluoranthren } \\
\text { e }\end{array}$ & nd & $0.0453 \pm 1.5$ & nd \\
\hline $\begin{array}{l}\text { Benzo[k]fluoranthren } \\
\text { e }\end{array}$ & nd & $0.0389 \pm 1.4$ & nd \\
\hline Benzo[a]pyrene & nd & nd & nd \\
\hline $\begin{array}{l}\text { Indeno[1,2,3-cd] } \\
\text { perylene }\end{array}$ & nd & nd & nd \\
\hline $\begin{array}{l}\text { Dibenzo[a,h]anthrace } \\
\text { ne }\end{array}$ & nd & nd & nd \\
\hline Benzo[g,h,i] perylene & nd & nd & nd \\
\hline Total & $\begin{array}{l}0.0184 \pm 0 . \\
02\end{array}$ & $0.1385 \pm 0.2$ & $0.0381 \pm 0.03$ \\
\hline
\end{tabular}

Values represent mean \pm standard deviation of three replicates; $n d=$ not detected

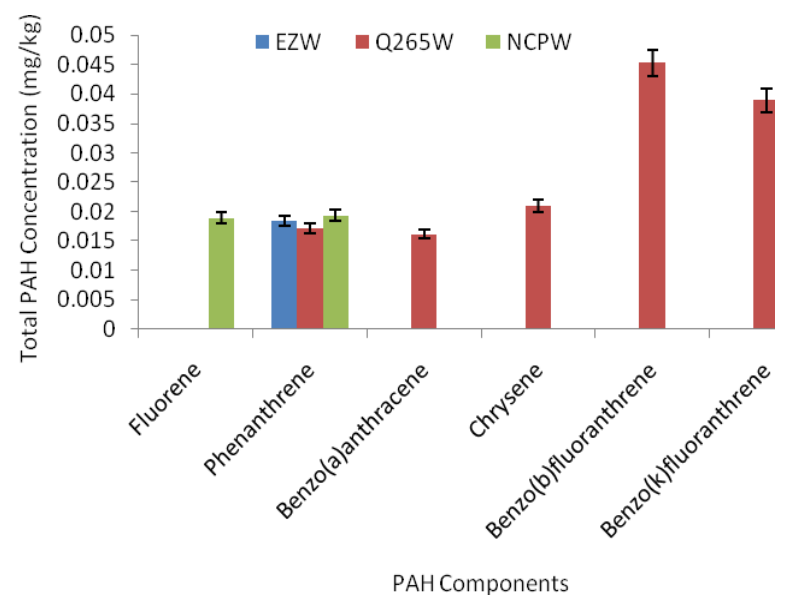

Fig. 2: Total Concentration of PAH detected in each of the Soil Samples 

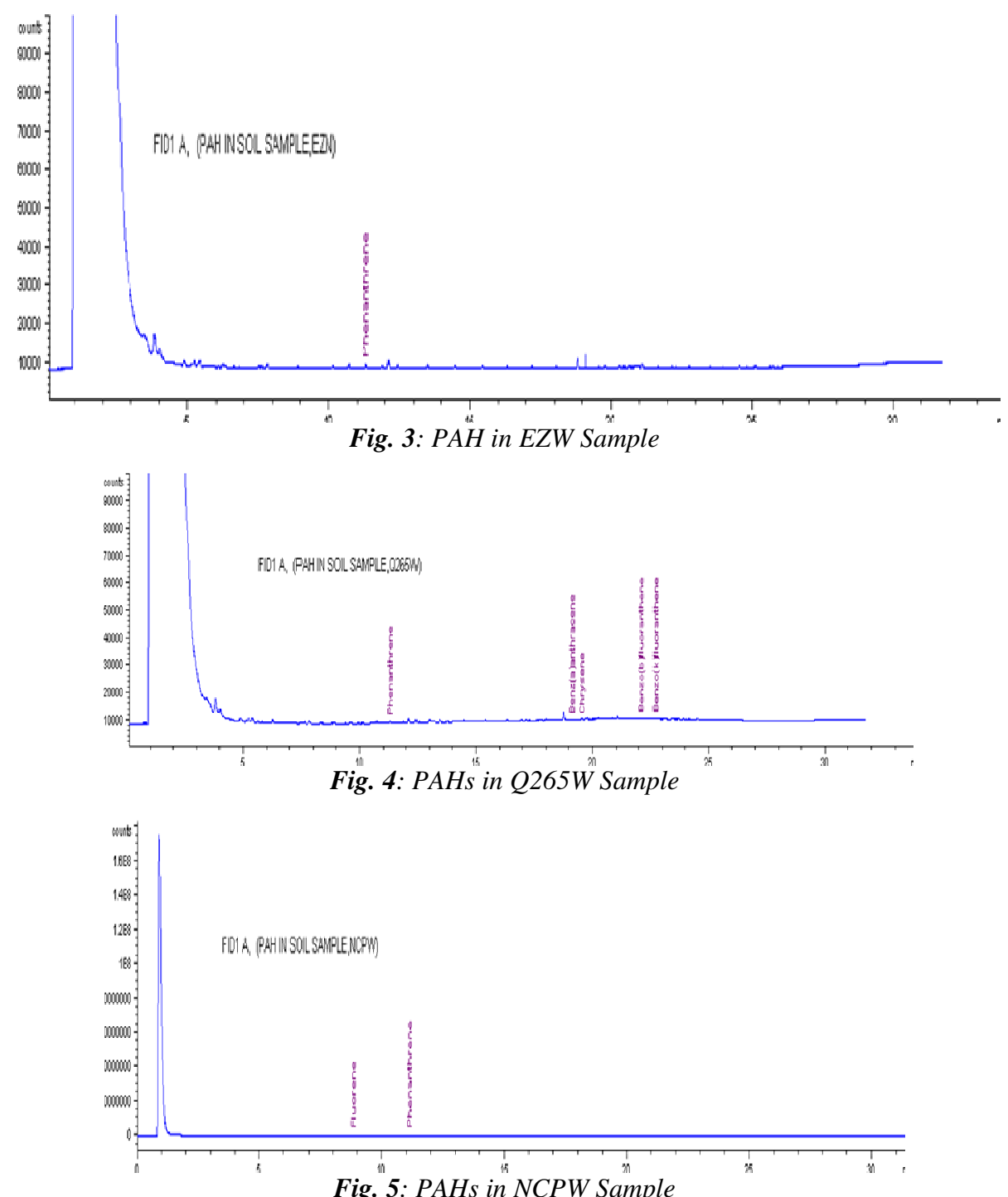

The results of the concentration $(\mathrm{mg} / \mathrm{kg})$ of the 16 EPA PAH compounds investigated in the contaminated soil site as shown in Table 1 and Fig. 2 respectively, indicated the presence phenanthrene in the studied composite samples. Concentration of phenanthrene ranged from $0.0172 \pm 0.01$ to $0.0193 \pm 0.02$ in all the samples. Sample Q265W showed the highest number of PAHs namely, phenathrene $(0.0172 \pm 0.01), \quad$ benzo[a]anthracene, (0.0162 \pm 0.05$), \quad$ chrysene $\quad(0.0209 \pm 0.02)$, benzo[b]fluoranthrene $\quad(0.0453 \pm 0.02) \quad$ and benzo[k]fluoranthrene $(0.0389 \pm 0.1)$ at varing concentrations that are significantly different. In sample NCPW, only flourene and phenanthrene were detected. The total PAH concentration in the samples differed significantly with sample Q265W having the highest PAH concentration load of $0.1385 \pm 0.2$ and sample EZW had least $(0.0184 \pm 0.02)$. The very low molecular weight PAHs such as naphthalene, acenaphthalene and acenaphthene were not detected probably due to the high volatilization or dissolution which may have occurred during the process of extraction. It may also be due to the length of time of exposure of the soil samples prior to this study.

The results also showed that phenanthrene and benzo[b]fluoranthene PAHs constituted the largest group of compounds with high concentrations in a typical soil sample contaminated with used engine oils, with the low molecular weight phenanthrene being more dominant with relatively lower concentrations compared to benzo[b]fluoranthene. It is evident from the results that the soils of Abakaliki auto-mechanic site were contaminated with PAHs at varying concentrations. However the total PAH concentrations were very low when compared with the maximum background limits of $15 \mathrm{mg} / \mathrm{kg}$ and $50 \mathrm{mg} / \mathrm{kg}$ in polluted soils set by Dutch and Polish

\section{U. OBINI; C.O. OKAFOR; J.N. AFIUKWA}


Environment Ministries respectively, (Polish Environment Ministry, 2002). This low values recorded in this study should not be taken for granted since there is no threshold concentration below which carcinogenic effects of PAH does not occur. The six PAH components detected fall within the category of PAHs with the highest health risk especially at prolonged exposure (ATSDR, 1999a). Four out of the six PAHs namely benzo(a)anthracene, chrysene, benzo(b)fluoranthrene and benzo(k)fluoranthrene are implicated as carcinogens according to the US-EPA (California Environmental Protection Agency, 1994). Conseqently, it is feared that the population of people living in and around the Abakaliki auto-mechanic village may be predisposed to high risk of cancer due to long-term exposure to PAH compounds through contaminated soils and water.

The health effects of PAHs have been reviewed extensively. These effects depend mainly on the extent of exposure, dose, innate toxicity and exposure routes. Other pre-disposing factors include preexisting health status and age. There is risk of harm in both short and long term exposure especially among the artisans. PAHs are ubiquitous in the urban and rural environment. As a result, it is very common to detect levels of PAHs in soils even at low levels and its toxicity consideration is of utmost importance. PAHs pose a major threat in terms of its carcinogenic effects. Some studies have shown that heavy PAHs can induce dioxin-like activity and weakened estrogenic responses (Villeneuve et al., 2002).

The chemistry and toxicity of PAHs are best understood using benzo[a]pyrene which has been extensively studied with a well established chemistry of its carcinogenic effects (Lee and Shim, 2007). Its metabolites were said to be mutagenic and highly carcinogenic, and is listed as a Group 1 carcinogen by the International Agency for Research on Cancer (IARC). The compound is one of the benzopyrenes, formed by a benzene ring fused to pyrene, and is the result of incomplete combustion at temperatures between $300^{\circ} \mathrm{C}$ and $600^{\circ} \mathrm{C}$ (Aygün and Kabadayi, 2005). Benzo[a]pyrene toxicity results from its bioactivation to the ultimate toxic compound, benzo[a]pyrene-7, 8-dihydrodiol-9,10-epoxide (Shou et al., 1996). Benzo[a]pyrene-7,8-dihydrodiol-9,10epoxide is the carcinogenic product of three enzymatic reactions (Hao Jiang et al., 2007). Properly speaking, benzo[a]pyrene is a pro-carcinogen, meaning that the mechanism of carcinogenesis of benzo[a]pyrene depends on enzymatic metabolism of benzo[a]pyrene to the ultimate mutagen, which is benzo[a]pyrene diol epoxide. X-ray crystallographic and nuclear magnetic resonance structure studies show that this binding distorts the DNA (Shou et al., 1996) inducing mutations by perturbing the doublehelical DNA structure. This disrupts the normal process of copying DNA and induces mutations. This explains the occurrence of cancer after exposure (Eaton and Gallagher, 1994). Research also indicated that benzo[a]pyrene diol epoxide specifically targets and destroys the protective gene thereby leading to cancer (Pfeifer et al., 2002; Daniel, 2007).

Conclusion: It is evident from this study that the Abakaliki auto-mechanic site is gradually being contaminated with PAHs arising from indiscriminate disposal of spent crankcase engine oils. As the city is expanding with more business outlay emerging, recycling and re-use advocacy is being recommended to track the spread of waste oils in the environment. The risk associated with the PAHs components of the spent engine oils are grave and needed to be tracked and regularly monitored not only in soils but also in water, air, vegetables and other plants in the area.

Acknowledgement: The authors are grateful to Dukoria Laboratories Ltd Warri, Delta State, Nigeria for permission to use their GC-MS equipment for the analysis.

\section{REFERENCES}

Agency for Toxic Substances and Disease Registry (ATSDR) (1994). Toxicological profile for polycyclic aromatic hydrocarbons (PAHs). Atlanta, G.A: U.S. Department of Health and Human Services, Public Health Service.

ATSDR, (1995). "Chemical and physical information,"in Toxicological Profile for Polycyclic Aromatic Hydrocarbons (PAHs), ATSDR, Atlanta, Ga, USA. pp. 209-221.

ATSDR (Agency for Toxic Substances and Disease Registry) (1997). Toxicology profile for used mineral based crankcase oil. Department of Health and Human Services, Public Health Service Press, Atlanta, GA, USA.

ATSDR (1999a). Toxicological profile for ethylbenzene. Agency for Toxic Substances and Disease Registry, Public Health Service, U.S. Department of Health and Human Services, Atlanta, G.A. USA.

Aygün, S.F and Kabadayi .F (2005). Determination of benzo[a]pyrene in charcoal grilled meat samples by HPLC with fluorescence detection. International Journal of Food Sciences and Nutrition. 56 (8): 581-585.

BCERF-Breast Cancer and Environmental Risk Factors Program (2001). Polycyclic Aromatic Hydrocarbons and Breast Cancer Risk. 
(http://envirocancer.cornell.edu/). Retrieved 1012-2011. pp. 34- 45.

California Environmental Protection Agency (CalEPA). (1994). Memorandum, to Cal/EPA Departments, Boards, and Offices from Standards and Criteria Work Group, Office of Environmental Health Hazard Assessment. Subject: California Cancer Potency Factors. In: A methodology for using background PAHS to support remediation decisions (2000). ENVIRON Corporation Emeryville, California. p.32

Christopher, M. (2008). "Polycyclic Aromatic Hydrocarbons (PAHs) in Urban Soil: A Florida Risk Assessment Perspective," International Journal of Soil, Sediment and Water: 1 (2):1-14.

Chukwuma, M. (2012). Crude oil pollution raises cancer risk among Nigerians.

(http://africancancercenter.com/crudeoil.htm).Ret rieved 02-03-2012. pp.1-3

Daniel, W. N (2007). Data presented in research seminars

wikipedia.org/wiki/file/Benzo(a)pyrenemetabolism.sv g). Retrieved 05-01-2013.

Ekundayo, J .A, Aisueni .N, Benka-Coker, M .O (1989). The Effects of drilling fluids in some waste and burrow pits in western operational areas of Shell Petroleum Development Company of Nigeria Limited on the soil and water quality of the areas.Environmental Consultancy Service

Group, Consultancy Services Unit, University of Benin, Benin City, Nigeria. pp. 29.

Eaton .D.L and Gallagher, .E.P. (1994). Mechanisms of a flatoxincarcino genesis.Annu RevPharmacolToxicol. 34: pp. 135-172.

EPA (1984). Method Study 20, Method 610 (PNA's), EPA 600/4-84-063, National Technical Information Service, PB84-211614, Springfield, Virginia 22161, USA.

IDPH-Illinois Department of Public Health (2005). Environmental health fact

sheet:polycyclic aromatic hydrocarbons. (www.idph.s tate.il.us/envhealth/factsheets/polycyclicaromati chydrocarbons.htm). Retrieved 07- 02-2012. pp.1-4
Ipeaiyeda, A.R, and Dawodu, M. (2008). Heavy metals contamination of topsoil and dispersion in the vicinities of reclaimed auto-repair workshops in Iwo, Nigeria. Bull. Chem. Soc. Ethiopia, 22 (3):339-348.

Iwegbue, C.M (2007). Metal fractionation in soil profiles at automobile Mechanic Waste Dumps around Port Harcourt. Waste Manage. Res., 25 (6): 585-593.

Lane, D. A. (1989). The fate of polycyclic aromatic compounds in the atmosphere and during sampling. In:"Chemical analysis of polycyclic aromatic compounds.” T.Vo-Dinh (Ed.), J.Wiley \& Sons. USA pp.31-58.

Lee, B.M and Shim, G.A., (2007). Dietary exposure estimation of benzo[a]pyrene and cancer risk assessment. Journal of Toxicology and Environmental Health Part A. 70 (15-16):13911394.

Minnesota Pollution Control Agency (2008). Soil sample collection and analysis procedure. Guidance Document 4-04, Petroleum Remediation Program. 520 Lafayette Road, N., St. Paul ,Minnesota. pp. 1-10

Odjegba, V.J and Sadiq, A.O (2002). Effects of spent engine oil on the growth parameters, chlorophyll and protein levels of Amaranthus hybridus L. The Environmentalist 22: 23-28.

Olugboji, O.A and Ogunwole, O.A (2008). Use of spent engine oil. AU J.T. 12 (1): 67-71.

Pfeifer, G.P; Denissenko, M.F; Olivier, M; Tretyakova N, Hecht, S.S and Hainaut, P. (2002). Tobacco smoke carcinogens, DNA damage and p53 mutations in smokingassociated cancers. Oncogene 21 (48):74357451.

Phillips, D. H., (1999)."Polycyclic aromatic hydrocarbons in the diet," Mutation Research, 443 (1-2):139-147.

Polish Environment Ministry (2002). Quality standards for soils due to a particular PAH content. DZ.U.No.165. p. 135

Sharifi, M; Sadeghi, Y; Akbarpour, M (2007). Germination and growth of six plant species on contaminated soil with spent oil. Inter. J. Environ., Sci. Technol., 4 (4): 463-470.

Shou, M; Gonzalez, F.J, Gelboin, H.V. (1996). Stereoselective epoxidation and hydration at the 
K- region of polycyclic aromatic hydrocarbons by cDNA- expressed cytochromes P450 1A1, 1A2, andepoxide hydrolyses. Biochemistry. 10; 35(49): 1580-1581

Villeneuve, D. L., Khim, J. S., Kannan, K. and Giesy, J. P., (2002)."Relative potencies of individual polycyclic aromatic hydrocarbons to induce dioxinlike and estrogenic responses in three cell lines, "Environmental Toxicology, 17 (2): 128137.

Vwioko, D .E; Anoliefo G .O; Fashemi, S D (2006). Metals concentration in plant tissues of Ricinus communis L. (Castor Oil) grown in soil contaminated with spent lubricating oil. Journal of AppliedScience and Environmental Management, 10: 127-134
Wang, J., Jia, C.R., Wong, C.K., Wong, P.K (2000). Characterization of polycyclic aromatic hydrocarbon created in lubricating oils. Water, Air Soil Poll., 120: 381-396.

World Health Organization Regional Office for Europe Polynuclear aromatic hydrocarbons (PAHs). (1987). In: Air quality guidelines For Europe. 105-117. 